arterial catheter in five may have further predisposed these infants to the development of necrotising enterocolitis. ${ }^{20}$

A consequence of reduced blood flow to the lungs is reduced production of surfactant. ${ }^{21}$ Hypoxia also predisposes to pulmonary vasoconstriction $^{22}$ and failure to absorb lung liquid. This might account for the greater number of cases of respiratory disease seen in babies in group 1, with the associated complications of interstitial emphysema, pneumothorax, patent ductus arteriosus, and intraventricular haemorrhage. Similarly, reduction of blood flow and resultant hypoxia in a number of fetal tissues might explain the findings of thrombocytopenia, coagulopathy, and bleeding, which are recognisable components of disseminated intravascular coagulation-a known consequence of hypoxia. ${ }^{23}$ Curtailed blood flow to skin, muscle, and kidneys and consequent hypoxic damage would account for the severe peripheral oedema and renal failure seen in two babies in group 1.

Traditional criteria for assessing fetal health correlate well with asphyxia and therefore by definition alert the physician to severe compromise that is already present. The results of such an approach in our cases shows the need to devise other methods which would allow earlier diagnosis of critical fetal compromise before irreversible damage occurs. The assessment of fetal blood flow might form the basis of such a method. Though these blood flow findings are evident as much as three weeks in advance of an abnormal cardiotocogram, and the persistence of this phenomenon heralds a poorer outcome, the time scale of these events has not been clearly elucidated. When deciding the optimal time for delivery of such a compromised fetus a fine balance must be struck between the risks of prematurity and the sequelae of the circulatory effects described above. More detailed studies of the evolution and momentum of these changes in waveform pattern and possibly the use of additional techniques such as ultrasound guided fetal blood sampling ${ }^{24}$ are likely to advance our management of these high risk pregnancies.

We acknowledge the support of the Rank Foundation, Action Research for the Crippled Child, and Birthright.

\section{References}

Tejani N, Mann L. Diagnosis and management of the small for gestational age fetus. Clin Obstet Gynecol 1977;20:943-55.

2 Dobson PC, Abell DA, Beisher NA. Mortality and morbidity of fetal growth retardation. Aust NZ f Obstet Gynaecol 1981;21:69-72.

3 Commey JOO, Fitzhardinge PM. Handicap in the preterm small for gestational age infant. $f$ Pediatr 1979;94:779-86.

4 Stewart AL, Reynolds EOR. Improved prognosis for infants of very low birthweight. Pediatrics 1974;54:724-35.

5 Westgren $M$, Hormquist $P$, Ingemarsson I, Svenningsen N. Intrapartum fetal acidosis in preterm infants: fetal monitoring and long term morbidity. Obstet Gynecol 1984;63:355-9.

6 Lipper E, Lee KS, Gartner LM, Grellong B. Determinants of neurobehavioural outcome in low- T birth-weight infents. Pediarics 1981;67:502-5.

7 Griffin D, Bilardo K, Masini L, et al. Doppler blood flow waveforms in the descending thoracic aorta of the human fetus. Br $\mathcal{F}$ Obstet Gynaecol 1984;91:997-1006.

8 Trudinger BJ, Giles WB, Cook CM, Bombardieri J, Collins L. Fetal umbilical artery flow velocity $\stackrel{\vec{D}}{+}$ waveforms and placental resistance: clinical significance. Br f Obstet Gynaecol 1985;92:23-30. Skidmore R, Woodcock JP. Physiological interpretation of Doppler shifted waveforms: I. Theoretical considerations. Ultrasound Med Biol 1980;6:7-10.

10 Cohn HE, Sacks EJ, Heymann MA, Rudolph AM. Cardiovascular responses to hypoxemia and $\overline{\bar{\omega}}$ acidemia in fetal lambs. Am $\mathcal{f}$ Obstet Gymecol 1974;120:817-24.

11 Behrman RE, Lees MH, Petersen EN, De Lannoy CW, Seeds AE. Distribution of the circulation in the normal and asphyxiated fetal primate. Am $\mathcal{F}$ Obstet Gynecol 1970;108:956-69.

12 Smalls M, Forbes JF. Centile values of birthweight for gestational age in Scottish infants. Glasgow: Social, Paediatric, and Obstetric Research Unit, University of Glasgow, 1983.

13 Royal College of Obstetricians and Gynaecologists Working Party on Routine Ultrasound

14 Campbell S, Thoms A. Ultrasound measurement of the fetal head to abdomen circumference ratio $\vec{\omega}$ in the assessment of growth retardation. Br 7 Obstet Gynaecol 1977;84:165-74.

15 in the assessment of growth retardation. Brf Obstel Gynaecol $1977,04: 165-74$. pregnancy. Br $\mathcal{F}$ Obstet Gynaecol 1980;87:780-5.

16 Pourcelot L. Application clinique de l'examen Doppler transcutane. In: Peronneau P, ed. Velocimetric ultrasonor Doppler. Paris: INSERM, 1974:213-40.

17 Gosling RG, King DH. Ultrasound angiology. In: Marcus AW, Adamon L, eds. Areries and veins. Edinburgh: Churchill Livingstone, 1975:61-8.

18 Reuss ML, Parer JT, Harris JL, Krueger TR. Hemodynamic effects of alpha-adrenergic blockade of during hypoxia in fetal sheep. Am $\mathcal{F}$ Obstet Gynecol 1982;142:410-5.

19 Touloukian RJ, Posch JN, Spencer R. The pathogenesis of ischemic gastro-enterocolitis of the neonate; selective gut mucosal ischemia in asphyxiated neonatal piglets. $f$ Pediatr Surg $\sigma$ 1972;7:194-205.

20 Kliegman RM, Fonaroff AA. Necrotising enterocolitis. N Engl f Med 1984;310:1093-1103.

21 Strang LB, ed. In: Neonatal respiration-physiological and clinical studies. Oxford: Blackwell $\omega$ Scientific, 1977:195-6.

22 Rudolph AM, Yuan S. Response of the pulmonary vasculature to hypoxia and $\mathrm{H}^{+}$ion concentration changes. J Clin Invest 1966;45:399-411.

23 Chessels JM, Wigglesworth JS. Coagulation studies in severe birth asphyxia. Arch Dis Child 1971;46:253-411.

24 Daffos F, Capella-Pavloski M, Forestier F. Fetal blood sampling via the umbilical cord using a $\vec{\bullet}$ needle guided by ultrasound. Report of 66 cases. Prenat Diagn 1983;3:271-7.

(Accepted I September 1986)

\title{
Snoring as a risk factor for ischaemic heart disease and stroke in men
}

\author{
MARKKU KOSKENVUO, JAAKKO KAPRIO, TIINA TELAKIVI, MARKKU PARTINEN, \\ KAUKO HEIKKILÄ, SEPPO SARNA
}

\begin{abstract}
The association of snoring with ischaemic heart disease and stroke was studied prospectively in 4388 men aged 40-69. The men were asked, in a questionnaire sent to them, whether they snored habitually, frequently, occasionally, or never. Hospital records and death certificates were checked for the next three years to establish how many of the men developed ischaemic heart disease or stroke: the numbers were 149 and 42, respectively. Three categories of snoring were used for analysis: habitual and frequent snorers $(n=1294)$, occasional snorers $(n=$ 2614), and non-snorers $(n=480)$. The age adjusted relative risk of ischaemic heart disease between habitual plus frequent snorers and non-snorers was $1.91(p<0.01)$ and for ischaemic heart disease or stroke, or both, $2.38(p<0.001)$. There were no cases of stroke among the non-snorers. Adjustment for age, body mass index, history of hypertension, smoking, and alcohol use did not significantly decrease the relative risks, which were 1.71 $(p>0.05)$ for ischaemic heart disease and $2.08(p<0.01)$ for
\end{abstract}

ischaemic heart disease and stroke combined. At the beginning of $\stackrel{N}{\curvearrowright}$ follow up in 1981, 462 men reported a history of angina pectoris or myocardial infarction. For them the relative risk of ischaemic heart disease between habitual plus frequent snorers and non- $N$ snorers was 1.30 (NS); for men without previous ischaemic heart $\omega$ disease $2.72(p<0.05)$.

Snoring seems to be a potential determinant of risk of ischaemic heart disease and stroke.

\section{Introduction}

Heavy snoring, which is almost always present in obstructive sleep $\frac{\mathbb{Q}}{\triangle}$ apnoea, seems to be associated with arterial hypertension. ${ }^{1-6}$ During sleep patients with apnoea may develop hypoxaemia and hypercapnia in association with increased pulmonary and systemic arterial pressure and increased susceptibility to cardiac arrhythmias. ${ }^{711}$ The cardiac index decreases during an apnoeic episode and $\frac{\overline{0}}{\partial}$ increases appreciably at the resumption of ventilation. ${ }^{12}$ There is 
BRITISH MEDICAL JOURNAL VOLUME $294 \quad 3$ JANUARY 1987

mounting evidence for an association between snoring and cardiovascular disease. Cross sectional surveys have indicated an association with ischaemic heart disease ${ }^{13}$ and angina pectoris ${ }^{6}$; the association with angina held even after adjustment for history of hypertension. A case-control study of patients with stroke found a relative risk of 2.8 for snoring and of 10.8 for habitual snoring. ${ }^{14} \mathrm{It}$ remains unclear whether snoring is associated with the risk of cardiovascular disease independently of hypertension and whether snorers who do not have sleep apnoea have an increased risk. Prospective studies of snoring in relation to cardiovascular disease have not been reported.

We investigated the predictive value of snoring for ischaemic heart disease and stroke during a three year follow up in a population of 4388 men aged 40-69. We studied only men because both snoring and cardiovascular disease are more common in men than women.

\section{Methods}

The Finnish twin cohort comprises adult twin pairs born in Finland before 1958. A postal questionnaire study of these twins was carried out in October and November 1981. The responses of men aged 40-69 (response rate $75 \%$ ) were selected for analysis. Among other things the questionnaire asked whether the subject never snored, sometimes snored, often snored, almost always snored, or could not say. Altogether $301(6.4 \%)$ of the men could not give their snoring state and $28(0.6 \%)$ did not answer the snoring question. Thus 4388 responses remained for analysis. Those who reported snoring almost always or often were considered to be "habitual snorers." Those who reported that they snored sometimes were considered to be "occasional snorers." The questionnaire also asked whether hypertension, angina pectoris, or myocardial infarction had been diagnosed by a doctor and for details of current drug treatment of hypertension. Subjects were classified into one of three groups according to whether they (1) were receiving current drug treatment for hypertension, (2) had had temporarily increased blood pressure but were not currently receiving drug treatment, or (3) did not have a history of hypertension. Weight and height were recorded and body mass index (weight/height ${ }^{2}$ ) calculated.

Subjects were classified into one of two categories according to their smoking habit: (1) non-smokers, occasional smokers, and ex-smokers ( $\mathrm{n}=$ 2873); and (2) current smokers ( $n=1384$ ). Data on smoking were missing for 34 men and on a history of ischaemic heart disease for 90 men (table I). The reported amount of alcohol used (the amounts of beer, wine, and spirits, separately, each month) was converted to grams of absolute alcohol. To establish the numbers of men who developed ischaemic heart disease or stroke records of ischaemic heart disease (International Classification of Diseases (eighth revision) 410-414) $(n=149)$ and stroke $($ ICD 431-438) $(n=$ 42) from a computerised nationwide hospital discharge register were scrutinised from 1 October 1981 to 31 December 1983, and records of death $(n=105)$ from a computerised nationwide population register were scrutinised from 1 October 1981 to 31 August 1984. Death certificates were collected from the Central Statistical Office: two were missing (one for a man who snored frequently and one for a non-snorer). The time of onset of symptoms was recorded in only a few cases of death from ischaemic heart disease. The time of death was recorded for $31(65 \%)$ of the 48 deaths from ischaemic heart disease.

The reliability of Finnish death certificate and hospital discharge data for ischaemic heart disease and stroke is satisfactory for epidemiological studies. ${ }^{15-17}$

The incidences of ischaemic heart disease and stroke (death or a hospital

Department of Public Health, University of Helsinki, 00290 Helsinki 29 ,
Finland
MARKKU KOSKENVUO, MD, acting associate professor of biometrics
JAAKKO KAPRIO, MD, researcher of the Finnish Academy
KAUKO HEIKKILÂ,, LICPHIL, systems analyst
SEPPO SARNA, PHD, acting professor of public health
Ullanlinna Sleep Disorders Clinic, Helsinki
TIINA TELAKIVI, MD, neurologist
Department of Neurology, University of Helsinki
MARKKU PARTINEN, MD, assistant professor
Correspondence to: Dr Koskenvuo.

record of the disease) were analysed by snoring state, contrasting (1) habitual plus frequent snorers with non-snorers and (2) habitual plus frequent snorers with occasional snorers plus non-snorers, using logistic models expressed as relative risks. ${ }^{18}$ The former risk was calculated from two snoring variables (habitual plus frequent snorers $v$ occasional snorers plus non-snorers, and habitual plus frequent plus occasional snorers $v$ nonsnorers). Ninety five per cent confidence intervals were calculated for the relative risk using the formula: $\exp (\hat{\beta} \pm 1.96 \mathrm{SE}(\hat{\beta}))$, where $\hat{\beta}$ is the $\beta$ coefficient in the logistic model. Adjustment was made for the effects of age, body mass index, history of hypertension, smoking state, and alcohol use. Analyses were also done separately for men free of ischaemic heart disease (not reporting angina pectoris or myocardial infarction at the beginning of follow up) and for men with ischaemic heart disease. Possible bias towards non-snorers was accounted for by excluding from the analysis men without a cohabiting partner $(n=410)$.

TABLE I-Numbers (\%) of men for whom data on smoking and previous ischaemic heart disease were missing by snoring category

\begin{tabular}{|c|c|c|c|c|}
\hline \multirow{3}{*}{$\begin{array}{l}\begin{array}{c}\text { Data on } \\
\text { smoking }\end{array} \\
\text { Present } \\
\text { Present } \\
\text { Missing } \\
\text { Missing }\end{array}$} & \multirow{3}{*}{ 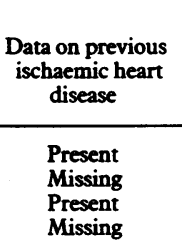 } & \multicolumn{3}{|c|}{ Snoring category } \\
\hline & & $\begin{array}{l}\text { Habitual and } \\
\text { frequent snorers }\end{array}$ & $\begin{array}{c}\text { Occasional } \\
\text { snorers }\end{array}$ & Non-snorers \\
\hline & & $\begin{array}{rr}1270 & (98 \cdot 1) \\
17 & (1 \cdot 3) \\
6 & (0.5) \\
1 & (0 \cdot 1)\end{array}$ & $\begin{array}{rr}2537 & (97 \cdot 1) \\
56 & (2 \cdot 1) \\
18 & (0 \cdot 7) \\
3 & (0 \cdot 1)\end{array}$ & $\begin{array}{rr}462 & (96.3) \\
12 & (2 \cdot 5) \\
5 & (1 \cdot 0) \\
1 & (0.2)\end{array}$ \\
\hline Total & & $1294(100 \cdot 0)$ & $2614(100 \cdot 0)$ & $480(100 \cdot 0)$ \\
\hline
\end{tabular}

\section{Results}

Table II shows the distribution of men by age and snoring category. During follow up ischaemic heart disease was recorded for 149 men (48 deaths and 120 hospital patients) and stroke for $\mathbf{4 2}$ men (five deaths and 42

TABLE II-Occurrence of snoring among men by age

\begin{tabular}{|c|c|c|c|c|c|}
\hline \multirow[b]{2}{*}{$\begin{array}{l}\text { Age } \\
\text { (years) }\end{array}$} & \multicolumn{4}{|c|}{ Snoring category } & \multirow{2}{*}{$\begin{array}{l}\text { Unknown } \\
\text { snoring } \\
\text { state }\end{array}$} \\
\hline & $\begin{array}{l}\text { frequent } \\
\text { snorers }\end{array}$ & $\begin{array}{l}\text { Occasional } \\
\text { snorers }\end{array}$ & Non-snorers & Total & \\
\hline $\begin{array}{l}40-49 \\
50-59 \\
60-69\end{array}$ & $\begin{array}{l}598 \\
496 \\
200\end{array}$ & $\begin{array}{r}1344 \\
921 \\
349\end{array}$ & $\begin{array}{r}260 \\
131 \\
89\end{array}$ & $\begin{array}{r}2202 \\
1548 \\
638\end{array}$ & $\begin{array}{r}171 \\
101 \\
57\end{array}$ \\
\hline Total (\%) & $1294(29)$ & $2614(60)$ & $480(11)$ & $4388(100)$ & 329 \\
\hline
\end{tabular}

TABLE III-Incidence of ischaemic heart disease and stroke expressed as percentage (and number of cases) by age and snoring category

\begin{tabular}{|c|c|c|c|c|}
\hline \multirow[b]{2}{*}{ Age (years) } & \multicolumn{4}{|c|}{ Snoring category } \\
\hline & $\begin{array}{l}\text { Habitual and } \\
\text { frequent snorers }\end{array}$ & $\begin{array}{l}\text { Occasional } \\
\text { snorers }\end{array}$ & Non-snorers & Total \\
\hline \multicolumn{5}{|c|}{ Ischaemic heart disease } \\
\hline $\begin{array}{l}40-49 \\
50-59 \\
60-69\end{array}$ & $\begin{array}{l}2.5(15) \\
6.7(33) \\
6.5(13)\end{array}$ & $\begin{array}{ll}1.4 & (19) \\
3.7 & (34) \\
6.6 & (23)\end{array}$ & $\begin{array}{ll}0.0 & (0) \\
6.1 & (8) \\
4.5 & (4)\end{array}$ & $\begin{array}{ll}1.5 & (34) \\
4.8 & (75) \\
6.3 & (40)\end{array}$ \\
\hline Total & $4 \cdot 6(61)$ & $3.0(76)$ & $2 \cdot 8(12)$ & $3.4(149)$ \\
\hline \multicolumn{5}{|c|}{ Stroke } \\
\hline $\begin{array}{l}40-49 \\
50-59 \\
60-69\end{array}$ & $\begin{array}{ll}0.8 & (5) \\
1.4 & (7) \\
2.0 & (4)\end{array}$ & $\begin{array}{rr}0.3 & (4) \\
1.3 & (12) \\
2.9 & (10)\end{array}$ & $\begin{array}{l}0.0(0) \\
0.0(0) \\
0.0(0)\end{array}$ & $\begin{array}{lr}0.4 & (9) \\
1.2 & (19) \\
2.2 & (14)\end{array}$ \\
\hline Total & $1 \cdot 2(16)$ & $1 \cdot 0(26)$ & $0.0(0)$ & $0.9(42)$ \\
\hline \multicolumn{5}{|c|}{ Ischaemic heart disease or stroke, or both } \\
\hline $\begin{array}{l}40-49 \\
50-59 \\
60-69\end{array}$ & $\begin{array}{l}3 \cdot 3(20) \\
7 \cdot 9(39) \\
8 \cdot 0(16)\end{array}$ & $\begin{array}{ll}1.7 & (23) \\
5.0 & (46) \\
8.9 & (31)\end{array}$ & 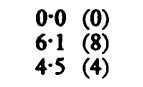 & $\begin{array}{ll}2 \cdot 0 & (43) \\
6.0 & (93) \\
8.0 & (51)\end{array}$ \\
\hline Total & $5 \cdot 6(75)$ & $3.9(100)$ & $2 \cdot 8(12)$ & $4 \cdot 3(187)$ \\
\hline
\end{tabular}


TABLE IV-Age adjusted mortality and snoring

\begin{tabular}{lcccc}
\hline & \multicolumn{3}{c}{ Mortality (\%) in snoring category } & Relative risk \\
\cline { 2 - 4 } & $\begin{array}{c}\text { Habitual and } \\
\text { frequent snorers }\end{array}$ & $\begin{array}{c}\text { Occasional } \\
\text { snorers and } \\
\text { non-snorers }\end{array}$ & $\begin{array}{c}\text { (95\% } \\
\text { confidence } \\
\text { intervals) }\end{array}$ & $\begin{array}{c}\text { No of } \\
\text { deaths }\end{array}$ \\
\hline Cardiovascular disease & 1.88 & 1.19 & $\begin{array}{c}1.58 \\
(1.05 \text { to } 2.38) \\
0.71\end{array}$ & 61 \\
Other diseases & 0.52 & 0.73 & $\begin{array}{c}0.31 \text { to } 1.63) \\
1.55\end{array}$ & 15 \\
Violent death & 0.45 & 0.29 & $(0.63$ to 3.81$)$ & 105 \\
\hline Total & 2.85 & 2.21 & $\begin{array}{c}1.29 \\
(0.92 \text { to } 1.81)\end{array}$ & 105 \\
\hline
\end{tabular}

TABLE $\mathrm{V}-$ Snoring and relative risk of ischaemic heart disease and of combined ischaemic heart disease and stroke in multiple logistic models. Values are age adjusted relative risks (and 95\% confidence intervals)

\begin{tabular}{lcc}
\hline & $\begin{array}{c}\text { Habitual+frequent snorers } v \\
\text { occasional snorers +non-snorers }\end{array}$ & $\begin{array}{c}\text { Habitual +frequent snorers } v \\
\text { non-snorers }\end{array}$ \\
\hline Snoring alone & \multicolumn{1}{c}{ Ischaemic hear disease } \\
Snoring & $1.61(1.15$ to 2.26$)$ & $1.91(1.18$ to 3.09$)$ \\
Body mass index & $1.40(1.15$ to 1.71$)$ & $1.71(0.96$ to 3.05$)$ \\
Hypertension & $1.07) 1.01$ to 1.13$)$ & $1.07(1.01$ to 1.13$)$ \\
Smoking & $1.86(1.49$ to 2.32$)$ & $1.86(1.49$ to 2.32$)$ \\
Alcohol use & $2.16(1.44$ to 3.25$)$ & $2.17(1.44$ to 3.27$)$ \\
& $0.98(0.90$ to 1.02$)$ & $0.98(0.93$ to 1.02$)$ \\
Snoring alone & Ischaemic hear disease or stroke, or both \\
Snoring & $1.57(1.16$ to 2.12$)$ & $2.38(1.50$ to 3.77$)$ \\
Body mass index & $1.28(0.90$ to 1.81$)$ & $2.08(1.20$ to 3.62$)$ \\
Hypertension & $1.08(1.03$ to 1.13$)$ & $1.08(1.03$ to 1.13$)$ \\
Smoking & $1.78(1.46$ to 2.18$)$ & $1.79(1.46$ to 2.18$)$ \\
Alcohol use & $1.92(1.33$ to 2.77$)$ & $1.93(1.34$ to 2.80$)$ \\
\hline
\end{tabular}

plus frequent snorers and occasional snorers plus non-snorers. The relative risk of death from stroke was $3.59(p>0.05)$ between habitual plus frequent snorers and occasional snorers plus non-snorers.

The age adjusted relative risk of an ischaemic heart disease event (death or hospital episode) between habitual plus frequent snorers and non-snorers was $1.91(\mathrm{p}<0.01)$ and of ischaemic heart disease or stroke, or both, 2.38 $(p<0.001)$ (table V). The group of non-snorers did not include any men with stroke (observed:estimated $=0: 4 \cdot 33 ; p=0.013$ according to Poisson distribution). The estimated relative risk of stroke (extrapolated from the risk of ischaemic heart disease or stroke, or both, and the risk of ischaemic heart disease) between habitual plus frequent snorers and non-snorers was 3.87 $(\mathrm{p}<0.01)$.

The age adjusted relative risks between habitual plus frequent snorers and occasional snorers plus non-snorers were $1.61(\mathrm{p}<0.01)$ for an ischaemic heart disease event, 1.40 (NS) for stroke, and $1.57(\mathrm{p}<0.01)$ for ischaemic heart disease or stroke, or both. Adjustment for age, body mass index, history of hypertension, smoking, and alcohol use did not significantly decrease the association between snoring and incidence of disease: the relative risk between habitual plus frequent snorers and non-snorers was 1.71 for ischaemic heart disease $(p>0.05)$ and $2.08(p<0.01)$ for ischaemic heart disease or stroke, or both (table V). The exclusion from the analysis of men without cohabiting partners did not essentially change the results: the relative risk between habitual plus frequent snorers and non-snorers for ischaemic heart disease was $1.81(p<0.05)$ and for ischaemic heart disease or stroke, or both, $2 \cdot 26(\mathrm{p}<0.05)$.

At the beginning of the follow up 462 men reported angina pectoris or myocardial infarction. Ischaemic heart disease was recorded in $\mathbf{8 0}$ of these men and stroke in 10 . The relative risk of ischaemic heart disease between habitual plus frequent snorers and non-snorers was 1.30 (NS) and between habitual plus frequent snorers and occasional snorers plus non-snorers 1.03 (NS). In men without previous ischaemic heart disease the corresponding ratios were $2.72(p<0.05)$ and $1.89(p<0.05)$. Table VI shows the age adjusted incidence and relative risk of ischaemic heart disease and stroke for men with and without previous ischaemic heart disease by snoring category.

The diurnal distribution of deaths from ischaemic heart disease showed a non-significant difference: $91 \%(10 / 11)$ of habitual and frequent snorers and $55 \%(11 / 20)$ of occasional snorers and non-snorers died before $4 \mathrm{pm}$.

TABLE VI-Age adjusted cumulative incidence and relative risk of ischaemic heart disease (IHD) and stroke by snoring category during follow up in men without and with previous ischaemic heart disease

\begin{tabular}{|c|c|c|c|c|}
\hline & \multicolumn{2}{|c|}{ Cumulative incidence (\%) } & \multicolumn{2}{|c|}{ Relative risk (and 95\% confidence interval) } \\
\hline & $\begin{array}{l}\text { Habitual+frequent } \\
\text { snorers }\end{array}$ & $\begin{array}{l}\text { Occasional snorers }+ \\
\text { non-scorers }\end{array}$ & $\begin{array}{l}\text { Habitual+frequent snorers } v \\
\text { occasional snorers +non-snorers }\end{array}$ & $\begin{array}{c}\text { Habitual + frequent snorers } v \\
\text { non-snorers }\end{array}$ \\
\hline \multicolumn{5}{|c|}{ Incidence of IHD } \\
\hline $\begin{array}{l}\text { Men free of IHD } \\
\text { All men } \\
\text { Men with previous IHD }\end{array}$ & $\begin{array}{r}2 \cdot 6 \\
4 \cdot 6 \\
19 \cdot 0\end{array}$ & $\begin{array}{r}1.4 \\
2.9 \\
15 \cdot 8\end{array}$ & $\begin{array}{l}1.89(1.17 \text { to } 3.07) \\
1.61(1.15 \text { to } 2.26) \\
1.03(0.63 \text { to } 1.70)\end{array}$ & $\begin{array}{l}2.72(1.24 \text { to } 5.97) \\
1.91(1.18 \text { to } 3.09) \\
1.30(0.63 \text { to } 2.68)\end{array}$ \\
\hline \multicolumn{5}{|c|}{ Incidence of stroke } \\
\hline $\begin{array}{l}\text { Men free of IHD } \\
\text { All men } \\
\text { Men with previous IHD }\end{array}$ & $\begin{array}{l}1 \cdot 1 \\
1 \cdot 2 \\
1 \cdot 9\end{array}$ & $\begin{array}{l}0.7 \\
0.9 \\
2 \cdot 1\end{array}$ & $\begin{array}{l}1.66(0.82 \text { to } 3.38) \\
1.40(0.82 \text { to } 2.38) \\
0.69(0.18 \text { to } 2.71)\end{array}$ & $\begin{array}{l}\text { NA } \\
\text { NA } \\
\text { NA }\end{array}$ \\
\hline \multicolumn{5}{|c|}{ Combined incidence of IHD and stroke } \\
\hline $\begin{array}{l}\text { Men free of IHD } \\
\text { All men } \\
\text { Men with previous IHD }\end{array}$ & $\begin{array}{r}3.5 \\
5.6 \\
20.9\end{array}$ & $\begin{array}{r}2 \cdot 1 \\
3 \cdot 7 \\
17 \cdot 7\end{array}$ & $\begin{array}{l}1.78(1.18 \text { to } 2.68) \\
1.57(1.16 \text { to } 2 \cdot 12) \\
1.06(0.66 \text { to } 1.70)\end{array}$ & $\begin{array}{l}3.65(1.83 \text { to } 7.29) \\
2.38(1.50 \text { to } 3.77) \\
1.60(0.85 \text { to } 3.01)\end{array}$ \\
\hline
\end{tabular}

*In logistic regression model adjusting for age.

NA = Not applicable because no men with stroke among never snorers.

hospital patients). The total number of men with ischaemic heart disease and stroke was 187 (four men had both diseases) (table III).

Table IV shows the mortality during the 35 months of the study. The age adjusted mortality ratio between habitual plus frequent snorers and occasional snorers plus non-snorers was $1.58(p<0.05)$ for cardiovascular diseases, 0.71 (NS) for other diseases, and 1.55 (NS) for violent deaths. Forty eight men died from ischaemic heart disease during follow up: 19 habitual and frequent snorers, 27 occasional snorers, and two non-snorers. Mortality from ischaemic heart disease (per 100 000/year) in the cohort was 155,509 , and 806 for age groups 40-49,50-59, and 60-69; the corresponding figures for the Finnish population were 145, 537, and 1305 in 1982. Mortality from ischaemic heart disease was $\mathbf{5 0 3}$ in habitual and frequent snorers, 354 in occasional snorers, and 143 in non-snorers. The relative risk of death from ischaemic heart disease was 3.52 $(p<0.05)$ between habitual plus frequent snorers and non-snorers and $1.48(p>0.05)$ between habitual

\section{Discussion}

The response rate was $75 \%$ among men aged $40-69$ and $84 \%$ among the whole cohort. Mortality from ischaemic heart disease $\stackrel{?}{-}$ among the men who responded, however, did not differ much from that among all Finnish men of the same age. The ratio of mortality from ischaemic heart disease among the cohort to that among the general population was $107 \%$ in those aged $40-49,95 \%$ in those aged $50-59$, and $62 \%$ in those aged $60-69$. Thus selection operated only in the oldest age group.

In 1986 a sample of the men in this study $(n=38: 17$ habitual snorers, 10 occasional snorers, and 11 non-snorers) underwent sleep recording for a single night using the static charge sensitive bed method (Bio-Matt) for measuring body and respiratory movements, 
with a microphone to record snoring sound and an oximeter (BIOX III) to measure blood oxygen saturation transcutaneously (Telakivi $T$, et al; 8th European congress of sleep research, Hungary, 1986). Six (35\%) of the habitual snorers had an apnoea index exceeding 10 , indicating the sleep apnoea syndrome. Thus the preliminary estimate of the prevalence of sleep apnoea in men aged $40-69$ was $3 \%$ $(0.35 \times 0.09$, where $0.09=$ the prevalence of habitual snoring). The mean oxygen saturation during sleep was significantly lower in habitual snorers than non-snorers. A quarter of habitual snorers were found to have arterial hypertension requiring treatment, while the corresponding figure for non-snorers was $9 \%$.

Analysis of snoring spikes per hour of sleep showed that all men who reported snoring in the 1981 questionnaire also snored during the recordings. Four of the 11 men $(36 \%)$ who had reported never snoring, however, snored during sleep. Thus self reported snoring seems to correspond well with sleep laboratory findings in the case of habitual snorers but to be less reliable in the case of non-snorers, one of whom had an apnoea index of over 10 with a snoring index of over 7 . Thus the estimated relative risk between snorers and nonsnorers is probably underestimated. A previous report of men in this study showed that men living alone were less likely to report habitual snoring and more likely to classify themselves as nonsnorers than married subjects. ${ }^{6}$ The exclusion of such men from the analysis, however, did not change the results.

The validity of self reported hypertension and previous ischaemic heart disease can be questioned. The predictive value of these risk factors, however, was significant and expected in magnitude. Self reported use of alcohol (by the Finnish twin cohort) corresponded to $41 \%$ of the sales figures; this was a higher figure than that obtained in interview studies. The non-response rate in the questionnaire study of the Finnish twin cohort was $11 \%$ for the whole cohort, $27 \%$ for those who had been admitted to hospital because of alcoholism during the three years before the study, and $42 \%$ for those who had been admitted because of alcohol intoxication in the previous three years. The role of heavy alcohol use could not be estimated in this study. ${ }^{19}$

Earlier findings on the association of snoring with ischaemic heart disease $^{126{ }^{13}}$ and stroke ${ }^{14}$ are cross sectional. In this first prospective study snoring was associated with the age adjusted risk of ischaemic heart disease. The relative risk between snorers and non-snorers was $1.91(p<0.01)$. These results are consistent with earlier cross sectional findings, which indicated that habitual snorers might be at high risk of myocardial infarction. The association of snoring with ischaemic heart disease was independent of body mass index, hypertension, smoking, and alcohol use. The relative risk of ischaemic heart disease by snoring category was significant in healthy men (not reporting a history of angina pectoris or myocardial infarction) but not in men with previous ischaemic heart disease. The role of snoring as a risk factor seems to decrease after the first ischaemic event - that is, the role of other risk factors increases. The incidence of ischaemic heart disease, however, was high $(17 \%)$ in men with previous ischaemic heart disease compared with men without (2\%). Possibly, self reporting of snoring is less valid among men with ischaemic heart disease compared with men without.

Snoring was also associated with the risk of stroke. It was not possible to calculate the relative risk between habitual plus frequent snorers and non-snorers as there were no cases of stroke among the non-snorers $(p=0.013)$. The risk of stroke between habitual plus frequent and occasional snorers was small $(1 \cdot 2 \% v 1 \cdot 0 \%)$.

Present knowledge of the pathophysiology of sleep apnoea suggests that the increased incidence of cardiovascular diseases in snorers is best explained by obstructive sleep apnoea. Some reports on populations of working age suggest a prevalence of $1-2 \% .^{20} 21$ Obstructive sleep apnoea is characterised by periodic episodes of apnoea and total collapse of the upper airway during sleep. The frequency and duration of apnoea vary. In the most severe cases there may be more than 300 apnoeic episodes during one night with a duration of 10-30 s. ${ }^{3}$ In heavy snorers with sleep apnoea the blood oxygen saturation during sleep decreases significantly. In severe sleep apnoea oxygen saturation may fall below $70 \%$; it is normally over $95 \% .^{4}$ After an apnoeic episode the pulmonary and systemic arterial pressure increase temporarily, ${ }^{12}$ straining the heart, es- pecially the right side, and the susceptibility to cardiac arrhythmias is increased..$^{7-11}$

A recent study reported an appreciable circadian rhythm in the onset of acute myocardial infarction, with a threefold increase in the morning. ${ }^{22}$ This may be related to preceding nocturnal myocardial ischaemia. In this study the time of onset of symptoms was not recorded in most of the death certificates. The time of death from ischaemic heart disease was recorded in $65 \%$ of cases. Probably a substantial proportion of the men whose time of death was unknown (35\%) died when they were asleep. The diurnal distribution of deaths from ischaemic heart disease, however, showed a nonsignificant difference by snoring state, suggesting that the time of death of snorers was earlier than that of non-snorers.

We can speculate that low oxygen saturation in patients with apnoea during sleep has an unfavourable effect on the activity of lipoprotein receptors, leading to increased serum low density lipoprotein cholesterol concentrations. ${ }^{23}$ There are no reports of the relation of sleep apnoea to blood lipid concentrations. In a subsample of this study $(n=91)$ total cholesterol, low density lipoprotein cholesterol, and high density lipoprotein cholesterol concentrations were analysed by snoring state and no differences found (unpublished data). The role of thrombocyte aggregation and coronary spasm in sleep apnoea is unclear.

The results of this study suggest that snoring may be an important determinant of the risk of ischaemic heart disease and that the risk associated with snoring is independent of body mass index, hypertension, and smoking. Snoring also predicted stroke, but the number of cases was small for detailed analysis.

This study was supported by a grant from the Council for Tobacco research, USA-Inc. MP has been supported by the Paavo Nurmi Foundation.

\section{References}

1 Lugaresi E, Cirignotta F, Coccagna G, Piana C. Some epidemiological data on snoring and cardiocirculatory disturbances. Sleep 1980;3:221-4.

Partinen M, Alihanka J, Lang H, Kalliomäki L. Myocardial infarction in relation to sleeep apneas. Sleep Research 1983;12:272.

3 Lavie P, Ben-Yosef R, Rubin AE. Prevalence of sleep apnea among patients with essential hypertension. Am Hean $\mathcal{I}$ 1984;108:373-6.

Kales A, Bixler E, Cadieux RJ, et al. Sleep apnoea in a hypertensive population. Lance 1984;ii: 1005-8

5 Fletcher EC, De Behnke RD, Lovoi MS, Gorin AB. Undiagnosed sleep apnea in patients with essential hypertension. Ann Intem Med 1985;103:190-5.

6 Koskenvuo M, Kaprio J, Partinen M, et al. Snoring as a risk factor for hypertension and angina pectoris. Lancet 1985; ;:893-6.

Schroeder JS, Motta J, Guilleminault C. Hemodynamic studies in sleep apnea. In: Guilleminault C, Dement WC, eds. Sleep apnea syndromes. New York: Alan R Liss Inc, 1978:177-96.

8 Tilkian AG, Motta J, Guilleminault C. Cardiac arrhythmias in sleep apnea. In: Guilleminault C, Dement WC, eds. Sleep apnea syndromes. New York: Alan R Liss Inc, 1978:197-210.

9 Deedwania PC, Swiryn S, Dhingra RC, Rosen KM. Nocturnal atrioventricular block as a manifestation of sleep apnea syndrome. Chest 1979;76:319-21.

10 Motta J, Guilleminault C. Cardiac dysfunction during sleep. Ann Clin Res 1985;17:190-8.

11 Ingbar DH, Gee JBL. Pathophysiology and treatment of sleep apnea. Annu Reo Med 1985;36: 369-95.

12 Guilleminault C, Motta J, Mihm F, Melvin K. Obstructive sleep apnea and cardiac index. Chest 1986;89:331-4.

13 Norton PG, Dunn EV. Snoring as a risk factor for disease: an epidemiological survey. $\mathrm{Br} \mathrm{Med} \mathcal{J}$ 1985;291:630-2.

14 Partinen M, Palomäki H. Snoring and cerebral infarction. Lancet 1985;ii:1325-6.

15 Pentrila A. Monality from aneriosclerotic and other degenerative heart diseases in Finland in 1968. Helsinki: National Board of Health, 1975. (Health Services Research of the National Board of Health in Finland 12/1974.)

16 Koskenvuo M, Kaprio J, Kesäniemi A, Sarna S. Differences in mortality from ischemic heart disease by marital status and social class. $\mathcal{J}$ Chronic Dis 1980;33:95-106.

17 Heliövaara M, Reunanen A, Aromaa A, et al. Validity of hospital discharge data in a prospective epidemiologic study on stroke and myocardial infarction. Acta Med Scand 1984;216:309-16.

epidemiologic study on stroke and myocardial infarction. Acta Med Scand 1984;216:309-16.
18 Dixon WJ, Brown MD, Engelman L, et al, eds. BMDP staristical software 1981. Los Angeles: University of California Press, 1981.

19 Koskenvuo M, Kaprio J, Kesäniemi A, et al. Alcohol-related diseases associated with ischaemic heart disease: a three-year follow-up of middle-aged male hospital patients. Alcohol Alcohol 1986;21:251-6.

20 Lavie P. Sleep apnea in industrial workers. In: Guilleminault C, Lugaresi E, eds. Sleep/wake disorders: natural histony, epidemiology, and long-term evolution. New York: Raven Press, 1983:127-35.

21 Peter JH, Siegrist J, Podszus T, et al. Prevalence of sleep apnea in heal thy industrial workers. Klin Wochenschr 1985;63:807-12.

22 Muller JE, Stone PH, Turi ZG, et al. Circadian variation in the frequency of onset of acute myocardial infarction. N Engl f Med 1985;313:1315-22.

23 Brown MS, Kovanen PT, Goldstein JL. Regulation of plasma cholesterol by lipoprotein receptors. Science 1981;212:628-35.

Accepted 13 October 1986) 